Михаило Шћепановић

Универзитет у Београду

Филолошки факултет

https://doi.org/10.18485/ai_zsjoski.2019.2.ch13

821.163.41.09-31 Тохољ М.

$811.163 .41 ' 367.635$

\title{
ОБЛИЦИ И СТИЛИСТИЧКА ФУНКЦИЈА НЕКИХ ЗАМЕНИЧКИХ ПРИЛОГА У РОМАНУ ЗВОНА ЗА ТРОЈИЦУ МИРОСЛАВА ТОХОљА
}

У овом раду осветљавамо, пре свега, неке дијалекатске облике заменичких прилога uīga, неīga и нuїga према њиховим стандарднојезичким еквивалентима uкag, некаg и никаg и пратимо њихову стилистичку функцију у роману Звона за Тројииу Мирослава Тохоља. Показало се да је роман базиран на догађања у ширем временском луку, а да се радња доноси у различитим временским пресецима. Може се закључити да се диференцијација између актуелног времена, тј. времена говорења и времена о којим се говори диференцира употребом различитих облика датих прилога, стандардних и нестандардних.

Кључне речи: заменице, заменички прилози, типови значења, семантички систем, семантичке категорије, Мирослав Тохољ

Заменички прилози у српском језику спадају у заменичке речи и деле са заменицама своје суштинске структурне и семантичке особине (Пипер1983:14-32). Они као и заменице одржавају трипартитни деиктички систем заснован на тројним основама (-в-, -т-, -н-), а који се односи на упућивање на учеснике у говорној ситуацији. Тако заменице и заменички прилози имају или йрокси- 
мално или меgијално или gисйално значење, што ће рећи да упућују на нешто у вези с говорником - проксимално (овај овде), са саговорником - медијално (тај ту), и нешто са предметом говора - дистално (онај, они) (в. Кордић 2002:71-72).

За разлику од заменица, ${ }^{1}$ заменички прилози шире свој систем мимо трипартитног деиктичног (овај, тај, онај) и прилагођавају га семантичком систему прилошког значења (месно, временско, начинско, узрочно).

Што се пак форми заменичких прилога тиче, оне су у савременом српском језику у оквиру појединих семантичких категорија стандардизоване и могу бити на пример потврдне или одричне, опште или пак неодређене, као на пример увек, нuкаg, uкag, некаg и управо то и јесте предмет нашег рада, али не на нивоу српског језика као целине, него с обзиром на употребу у књижевном тексту једнога писца, а то је роман Звона за Тројииу Мирослава Тохоља. Али не и с обзиром на све семантичке типове прилога, него само оне временске у потврдној, одричној, општој или неодређеној форми.

Зашто баш ово дело? Прво, и основно, дело је врло значајно јер прати вишевековни развој трију породица верски раздељених на простору данашње источне Херцеговине, коју писац, очито, једино и сматра Херцеговином. То, унеколико, показују занимљива запажања J. Делића у предговору ове књиге: „Наратор је неименован и обавијештен: завирио је у љетопис игумана Теодосија и

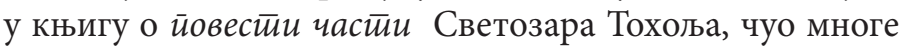
приче и свједочења, упутио се у историју. Рекло би се да следи објективно, спољашње приповиједање али ћемо се ускоро увјерити како та позиција приповједача није чврста, није фиксирана већ изразито флексибилна па и Тохољев наратор повремено преузима психолошку, иде-

1 О чијој функцији и значењу исцрпно пише И. Клајн (1985). 
олошку, фразеолошку или просторновременску тачку гледишта јунака, и тако привидно спољашња тачка гледишта постаје повремено унутрашња односно веома сложена" (Делић 2010: VIII).

У тако претпостављеном историјату Херцеговине, како је нагласио J. Делић, не само да се смењују времена и векови, него се смењују, нужно, и ликови и њихове судбине. Све ово једино обједињује виђење писца. Другачије речено, писац обједињава у свом језичком изразу који је истовремено и ауйорски, и нараторски (јер онај који приповеда и није писац $\left.{ }^{2}\right)$ - најмање две тачке гледишта: ауторску и нараторску. У тим двема тачкама преламају ce, посредно, и(ли) непосредно, кроз различите типове туђег говора и тачке гледишта самих ликова. Увек мимо управног говора. То нам индиректно у роману и сам аутор потврђује на 79. страни:

И ено, оних што су се онуда врзмали - једном неће бити. Она ствар са Мунковом лепом Меримом, показаће се идућег пролећа била је сасвим, сасвим у реду. Роди кћер Битуњанима и дадоше јој име исто као оном Врајлином ждребету - Акана. Порођајем се, сиротица, отрова, разболе и премину.

Онај који ово приповеда, њих кад се сети, бар оних душевних и добрих међу њима, уждије свећу покаткад, једнако на мезарима и гробовима, па чија весело гори, благо његовој души, а чија сузама воштаним капље - тај је на оном свету у стисци и невољи. Опомени их се, Господе, јер спашће књига, мора спасти, на три слова: j-ооо-j!.

2 у раду ћемо се служити термином ауйор да означимо приповедача првог, најширег наративног круга од многих у овом роману, тј. приповедача који је према позицији писцу најближи. За други наративни круг користимо термин наратор, а за остале говор ликова. Прва два круга су веома блиска, неприметно се смењују и одлике њихових говора представљају фокус интересовања овог рада. 
Пада у очи графостилемски у алонжманском облику ${ }^{3}$ дат узвик на крају цитираног параграфа, који на неки начин сугерише да у самом роману има мало екскурса управног говора. Све је укључено или опосредовано ауторским говором, или говором наратора тако да је врло тешко, мимо саме тачке гледишта разабрати шта стварно припада ауторском, шта говору наратора, а шта припада говору самих ликова. То је управо због тога што су они међусобно тако прожети да остављају дилему о границама различитих типова и подтипова ауторовог, говора наратора, и ликова. (О типовима туђег говора исцрпно говори Ковачевић 2012: 13-38).

Ова дилема се најбоље огледа у теми коју овде презентујемо, у теми о облицима и стилистичкој вредности неких заменичких прилога. Али нам није циљ да анализирамо све у роману употребљене заменичке прилоге. За предмет анализе узети су само заменички прилози који имају различите обличке варијанте, а свака варијанта па и обличка, нужно призива стилистичку, посебно због тога што су дати прилози употребљени у књижевноуметничком тексту, чија анализа не може заобићи стилистички аспект.

Наиме, оно што се у роману да уочити јесу, условно говорећи, gвоваријаниини облици йојеgиних временских заменичких йрилоїа мимо микродискурса управног говора, али с јасном диференцијацијом стандарднојезичких на једној, и дијалекатских ликова на другој страни. Међу тим прилозима најбројнији су временски заменички прилози одричног и неодређеног значења (типа: некада - неїga, никада - ниїga). Њима се још могу придружити и неодређено допусни прилози типа: икада uіga, који су неупоредиво ређи у употреби. То је сасвим

3 О алонжману и његовим стилским аспектима в. Бабић (20062007: 173-182). 
очекивано јер они имају неупоредиво ужу дистрибуцију, већ и самим тим што се не могу појавити у иницијалној позицији реченице.

Употреба наведених дијалекатских ликова датих облика и уз њихову историјско географску подршку нису дати под наводницима тј. нису дати у управном говору, односно нису правописно маркирани. То нам је полазна, али и додатна информација да претпоставимо да је вишеслојна структура Тохољевог романа нужно захтевала различите облике истих категорија речи да би се на основу њих могла вршити и одређена семантичка диференцијација, како у временској, тако и у персоналној хијерархији, а то се најбоље види и по неким другим прилозима које Тохољ употребљава износећи их из уже ареалног дијалекатског миљеа:

...сутра ћемо насути воде у котао, налити шишу сирћета па Брњаша с леве стране купати; прекосутра десну; Брњо не воли да се окупа цео накозакосуйра истрљаћемо га зејтином и с мало петролеја; опет само леву; наконакозакосуйра десну; после две недеље опет опрати , опет мазати уљем и гасом. (89). ${ }^{4}$

Својом необичношћу дати прилози директно привлаче пажњу читаоца и служе као диференцијална црта савременог српског језика, како смо претходним примером показали, према његовим архаичним или пак дијалекатски обојеним варијантама.

Управо због тога Тохољ употребљава ове потпуно архаичне облике (неīga, нuїga, uīga) у стандардном језику. Они су, наиме употребљени у (микро)дискурсима правописно немаркираним као управни говор. Заправо,

4 Број дат у загради односи се на страницу књиге наведене у Изворима на крају рада. Сва истицања у примерима су накнадна, тј. наша - М.Ш. 
упућени су на говор аутора или на говор наратора. Међутим, у ауторском говору срећу се и њихови стандардни варијетети (икада, некада, никада). Зато се и поставља питање: шта их диференцира? Чини се да их диференцира функција чисто одељеног ауторовог говора, у коме се сусрећу само стандарднојезички ликови и функција коју Бахтин дефинише као хибридни говор (Бахтин 1989:63), функција у којој се сусрећу говор аутора и говор лика, односно говор аутора и говор наратора.

У таквом привидно ауторовом говору нужно се евоцирају неауторске језичке особине које је најлакше показати кроз привидно дијалекатске форме прилога. Кад кажемо йривияно то је управо због тога што је сав контекст стандардан а сам прилог, будући да је по правилу временски, има улогу упућивања на неакйуелно сйане, односно да призива или захтева контекст који не припада ауторовом времену (тј. времену говорења), о чему сведоче и следећи примери:

...остављајући за собом сумњу да је од овог крда могуће иїga истесати ваљану коњицију. (27); ...онакав какав је неĭga био. (34); Умаче на своју страну и ниїgа се више не врати. (64); ...што је у комитском руху неїga по Босни војевао. (144); Поплаву, кугу и јарамство ниіga нису успевали да искорене. (145); ...jep нuіga се није ни сазнало чији су, кад, и одакле избише. (152); ...да се ниїgа не реже од себе него према себи, и преко руке да се, уз хлеб, не налива вином. (167); ...напослед снаћи заслужена срећа мада она нити је говорила, нити ичим показивала да томе, uiga посвећује пажњу (170); ...ca тридесетак Мариних кошница, мада у свом пчеларском сујеверју ниїga није одавала тачан број (176); Нuїgа и нипошто и ни у шта зелено себе неће оденут. (245); Huіga хумско племе, показало се, није оскудевало у вештим мајсторима за свакојаке послове. (285); И ниїg, то је у путу важно колико и неопходна резервна опрема, не скреће односе у друштву према подразумеваној полној разлици. (306) итд. 
С обзиром на чињеницу да је роман Звона за Тројииу Мирослава Тохоља уроњен у широки временски лук, и да временски „укршта” догађаје из различитих временских пресека, сасвим је очекивано да се диференцијација између актуелног времена и времена о којима се говори, успоставља употребом различитих облика прилога стандардних и нестандардних нпр: некаgа - рећи ће аутор из свог времена, према неїga - када наратор отпочне приповедати о времену о коме се говори. Овај закључак без сумње би потврдила овде неизвршена статистичка анализа свих примера употребљених прилога у овом Тохољевом роману.

\section{Извор}

Мирослав Тохољ, Звона за Тројицу, Београд: СКЗ, 102. Коло, 2010.

\section{Литература}

Бабић 2006-2007: Миланка Бабић, Алонжман као стилско

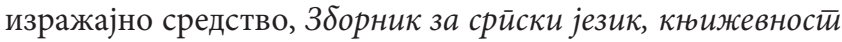
и умјетиности, VI/VII, бр. 3/4, Бањалука, 173-182.

Бахтин 1989: Mihail Bahtin, O romanu, Beograd: Nolit.

Делић 2010: Јован Делић, Отече младеж као вода, предговор роману Звона за Тројииу Мирослава Тохоља, Београд: СКЗ, VII-XXIV

Клајн 1985: Ivan Klajn, O funkciji i prirodi zamenica, Beograd: Institut za srpskohrvatski jezik.

Ковачевић 2012: Милош Ковачевић, О іраматичико-стиили-

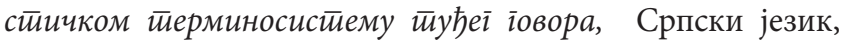
XVII, Београд, 2012, 13-38.

Кордић 2002: Snježana Kordić, Riječi na granici punoznačnosti, Zagreb: Hrvatska sveučilišna naklada.

Пипер 1983: Predrag Piper, Zamenički prilozi (gramatički status $i$ semantički tipovi), Novi Sad: Radovi instituta za strane jezike i književnosti. 
Mihailo Šćepanović

\section{DIE FORMEN UND STILISTISCHEN FUNKTIONEN VON PRONOMINALADVERBIEN IN DEM ROMAN GLOCKEN FÜR DREI VON MIROSLAV TOHOLJ}

In diesem Beitrag beleuchten wir, vor allem, einige dialektalen Formen der Pronominaladverbien jemals, dereinst und nirgendwo gemäß ihren Standardsprachlichen Äquivalenten irgendwann, ehemals und nie und verfolgen ihre stilistische Funktion in einem bestimmten literarischen Text von Miroslav Toholj. Es hat sich gezeigt, dass der Roman über die Ereignisse in einem breiteren Bogen der Zeit beruht, und dass die Handlung in verschiedenen Zeitabschnitten gebracht wird, man kann folgern, dass die Differenzierung zwischen der heutigen Zeit, dh. der Redezeit und der Zeit von der geredet unterschieden wird durch die Verwendung von verschiedenen Formen von gegeben Adverbien, Standard- und Nicht-Standardmäßigen.

Stichwörter: Pronomen, Pronominaladverbien, Bedeutungarten, semantisches System, semantische Kategorien, Miroslav Toholj 